\title{
Value preferences and consumer sustainable choices
}

\author{
dr hab. Grzegorz Zasuwa \\ Katolicki Uniwersytet Lubelski Jana Pawła II, Wydział Nauk Społecznych, Instytut Ekonomii i Zarządzania \\ ORCID: 0000-0003-4131-5079 \\ e-mail: gzasuwa@kul.Iublin.pl
}

\begin{abstract}
The article aims to show the influence of value preferences of Polish consumers on sustainable consumption. In order to achieve this goal, a set of research hypotheses was formulated, referring to both the theory of values and the theory of consumption. Data from a representative sample of 2120 respondents participating in the Social Diagnosis survey and the International Social Survey were used to verify the hypotheses formulated in such a way. The results show that those who indicate friends, cheerfulness and freedom as the most important values in their lives are more likely to select products for sustainable development goals than other consumers.
\end{abstract}

Keywords

sustainable consumption, personal values, Poland

Celem artykułu jest ukazanie wpływu preferencji wartości polskich konsumentów na zjawisko zrównoważonej konsumpcji. Dążąc do realizacji tego celu, sformułowano serię hipotez badawczych, odwołując się zarówno do teorii wartości, jak i teorii konsumpcji. Do weryfikacji hipotez wykorzystano dane $\mathrm{z}$ reprezentatywnej próby liczącej 2120 respondentów uczestniczących jednocześnie w badaniu Diagnoza Społeczna oraz Międzynarodowym Sondażu Społecznym. Uzyskane wyniki pokazują, że osoby wskazujące na przyjaciól, pogodę ducha oraz wolność jako najważniejsze w życiu wartości częściej dokonują wyborów rynkowych ze względu na cele zrównoważonego rozwoju niż pozostali konsumenci.

Slowa kluczowe

zrównoważona konsumpcja, wartości, Polska

JEL: M31, Q01

Str. 14-29

\section{Bibliografia/References}

Bylok, F. (2016). Meandry konsumpcji we współczesnym społeczeństwie: konsumpcjonizm versus dekonsumpcja. Annales. Etyka w życiu gospodarczym, 19(1), 55-69. https://doi.org/10.18778/1899-2226.19.1.04

Cieciuch, J. (2013). Kształtowanie się systemu wartości od dzieciństwa do wczesnej dorosłości. Warszawa: Liberi Libri.

Czapiński J. \& Panek T. (Eds.) (2015). Diagnoza społeczna. Retrieved from http://www.diagnoza.com

Dąbrowska, A. (2015). Postawy polskich konsumentów — od konsumpcjonizmu do zrównoważonej konsumpcji. Handel Wewnętrzny, 2(355), 88-100.

Follows, S. B. \& Jobber, D. (2000). Environmentally responsible purchase behavior: A test of a consumer model. European Journal of Marketing, 34(5/6), 723-746. https://doi.org/10.1108/03090560010322009

Gutman, J. (1997). Means-end chains as goal hierarchies. Psychology \& Marketing, 14(6), 545-560. https://doi.org/10.1002/(SICI)1520-6793(199709)14:6<545::AID-MAR2>3.0.CO;2-7

Kiełczewski, D. (2007). Struktura pojęcia konsumpcji zrównoważonej. Ekonomia i Środowisko, 2(32), 36-50.

Małysa-Kaleta, A. (2016). Misja konsumenta we współczesnym świecie. Handel Wewnętrzny, 4(363), 142-152.

Pepper, M., Jackson, T., \& Uzzell, D. (2009). An examination of the values that motivate socially conscious and frugal consumer behaviours. International Journal of Consumer Studies, 33(2), 126-136. https://doi.org/10.1111/j.14706431.2009.00753.x 
Schwartz, S. H., Cieciuch, J., Vecchione, M., Davidov, E., Fischer, R., Beierlein, C., Ramos, A., Verkasalo, M., Lönnqvist, J. -E., Demirutku, K., Dirilen--Gumus, O., \& Konty, M. (2012). Refining the theory of basic individual values. Journal of Personality and Social Psychology, 103(4), 663-668. https://doi.org/10.1037/a0029393

Schwartz, S. H. (1992). Universals in the content and structure of values: Theoretical advances and empirical tests in 20 countries. In M. Zanna (Ed.), Advances in Experimental Social Psychology (1-65). Orlando: Academic Press. https://doi.org/10.1016/S0065-2601(08)60281-6

Schwartz, S. H. (1994). Are there universal aspects in the structure and contents of human values? Journal of Social Issues, 50(4), 19-45. https://doi.org/10.1111/j.1540-4560.1994.tb01196.x

Sharma, R. \& Jha, M. (2017). Values influencing sustainable consumption behaviour: Exploring the contextual relationship. Journal of Business Research, 76, 77-88. https://doi.org/10.1016/j.jbusres.2017.03.010

Smyczek, S. (2015). Unowocześnianie konsumpcji a postawy etyczne konsumentów na rynkach finansowych. Studia Ekonomiczne, (231), 101-119.

Stanisz, S. (2006). Przystęny kurs statystyki z zastosowaniem STATISTICA PL na przykladach z medycyny. Tom 1. Statystyki podstawowe. Kraków: StatSoft.

Stern, P. C. \& Dietz, T. (1994). The value basis of environmental concern. Journal of Social Issues, 50(3), 65-84. https://doi.org/10.1111/j.1540-4560.1994.tb02420.x

Wasilik, K. (2014). Trendy w zachowaniach współczesnych konsumentów — konsumpcjonizm a konsumpcja zrównoważona. Konsumpcja i Rozwój, 1(6), 66-74.

Zalega, T. (2015). Zrównoważony rozwój a zrównoważona konsumpcja — wybrane aspekty. Konsumpcja i Rozwój, 4(13), 3-26. 